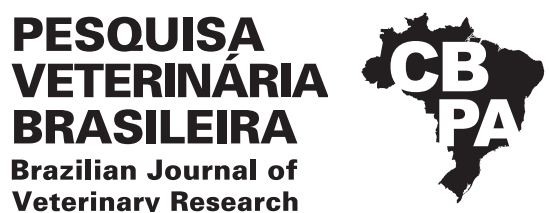

\title{
Enzootic calcinosis in sheep in Uruguay: a brief review and report of two outbreaks ${ }^{1}$
}

\author{
Mizael Machado ${ }^{2}$ (D) Carlos O. Schild ${ }^{2}$ (D) Marcela Preliasco ${ }^{3}$, Aldana Balserini ${ }^{4}$, \\ Rosane M.T. Medeiros ${ }^{5}$, Severo S. Barros ${ }^{6}$ (D) and Franklin Riet-Correa ${ }^{2,7 *}$ (D)
}

\begin{abstract}
Machado M., Schild C.O., Preliasco M., Balserini A., Medeiros R.M.T., Barros S.S. \& Riet-Correa F. 2020. Enzootic calcinosis in sheep in Uruguay: a brief review and report of two outbreaks. Pesquisa Veterinária Brasileira 40(11):831-836. Instituto Nacional de Investigación Agropecuaria, Plataforma de Salud Animal, Estación Experimental INIA Tacuarembó, Ruta 5 Km 386, Tacuarembó, Uruguay. E-mail: franklinrietcorrea@gmail.com

This study aimed to do a brief review of enzootic calcinosis in sheep and to report two outbreaks of Nierembergia rivularis poisoning in sheep in Uruguay. The outbreaks occurred in farms located on an island (Outbreak A) and on the border (Outbreak B) of the Rincón del Bonete lake. Sheep of all ages were affected, with the exception of suckling lambs. The first clinical signs occurred in early October, and deaths occurred from December to February. Outbreaks A and B had morbidity of $10 \%$, and the mortality was $7.2 \%$ and $2.8 \%$ in Outbreaks $A$ and B, respectively. The clinical signs included weight loss, retracted abdomen, stiff gait, and kyphosis. An autopsy was performed on one sheep from each outbreak. Pulmonary and arterial calcification, nephrocalcinosis, and osteopetrosis were observed in gross and microscopic examination in both sheep. Thyroid C-cell hyperplasia and carcinoma was observed in sheep A. Sheep B showed thyroid C-cell hyperplasia and parathyroid chief cell atrophy. The parathyroid was not examined in the sheep from Outbreak A. The differential diagnosis of enzootic calcinosis in southern South America should consider four toxic plants in the Solanaceae family: Solanum glaucophyllum, Solanum stuckertii, Nierembergia veitchii, and Nierembergia rivularis.
\end{abstract}

INDEX TERMS: Sheep diseases, enzootic calcinosis, Nierembergia, Uruguay.

RESUMO.- [Calcinose enzoótica em ovinos no Uruguai: revisão de literatura e descrição de dois surtos.] Este trabalho faz uma breve revisão da calcinose enzoótica em ovinos e descreve dois surtos de intoxicação por Nierembergia rivularis em ovinos no Uruguai. Os surtos ocorreram em propriedades localizadas em uma ilha (Surto A), e nas margens (Surto B) do lago do Rincón del Bonete. Foram afetados ovinos de todas as idades, exceto cordeiros lactentes. Os primeiros sinais clínicos ocorreram no início de outubro e as mortes de dezembro a fevereiro. Morbidade de $10 \%$ foi observada nos

\footnotetext{
${ }^{1}$ Received on August 8, 2020.

Accepted for publication on August 24, 2020.

Part of the Doctoral Thesis of the first author.

${ }^{2}$ Instituto Nacional de Investigación Agropecuaria, Plataforma de Salud Animal, Estación Experimental INIA Tacuarembó, Ruta 5 Km 386, Uruguay. *Corresponding author: franklinrietcorrea@gmail.com

${ }^{3}$ Departamento de Patobiología, División de Laboratorios Veterinarios, Ministerio de Ganadería, Agricultura y Pesca, Constituyente 1476, 11200 Montevideo, Departamento de Montevideo, Uruguay.
}

Surtos A e B. A mortalidade foi de 7,2\% e 2,8\% nos Surtos A e $\mathrm{B}$, respectivamente. Os sinais clínicos incluíram perda de peso, abdômen retraído, marcha rígida e cifose. Foram necropsiados um animal de cada rebanho. Observou-se mineralização arterial e pulmonar, nefrocalcinose e osteopetrose no exame macroscópico e histológico dos dois ovinos. Hiperplasia e carcinoma de células $\mathrm{C}$ da tireoide foram observados no ovino A. O ovino B apresentou hiperplasia de células C da tireoide e atrofia das células principais da paratireoide. As paratireoides do ovino $\mathrm{A}$ não foram examinadas. 0 diagnóstico

\footnotetext{
${ }^{4}$ División Sanidad Animal, Zonal Paso de los Toros, Ministerio de Ganadería, Agricultura y Pesca, Tacuarembó, 25 de Mayo 175, 45000 Tacuarembó, Departamento de Tacuarembó, Uruguay.

${ }^{5}$ Hospital Veterinário, Centro de Saúde e Tecnologia Rural (CSTR), Campos de Patos, Universidade Federal de Campina Grande, Patos, PB 58700-000, Brazil

${ }^{6}$ Departamento de Patologia Veterinária, Universidade Federal de Santa Maria (UFSM), Santa Maria, RS 97119-900, Brazil.

${ }^{7}$ Graduate Program in Animal Science in the Tropics, Escola de Medicina Veterinária e Zootecnia, Universidade Federal da Bahia (UFBA), Av. Adhemar de Barros 500, Ondina, Salvador, BA 40170-110, Brazil.
} 
diferencial da calcinose enzoótica no Sul da América do Sul deve considerar quatro plantas calcinogênicas da família Solanaceae: Solanum glaucophyllum, Solanum stuckertii, Nierembergia veitchii e Nierembergia rivularis.

TERMOS DE INDEXAÇÃO: Doenças de ovinos, calcinose enzoótica, Nierembergia, Uruguai.

\section{INTRODUCTION}

Poisoning by calcinogenic plants produces systemic soft tissue calcification in different animal species. Plants that are known to be calcinogenic in South America (Argentina, Brazil, and Uruguay) are Solanum glaucophyllum (syn. Solanum malacoxylon), which affects cattle (Döbereiner et al. 1971, Riet-Correa et al. 1975, Gimeno 2001), sheep (García y Santos et al. 2007), buffaloes (Santos et al. 2011), and equine (Odriozola et al. 2017); Solanum stukertii, which affects goats in Argentina (Iglesias et al. 2008, Rossanigo et al. 2017); Nierembergia veitchii (Barros et al. 1970, Riet-Correa et al. 1987, Rissi et al. 2007, 2009) and Nierembergia rivularis (syn. Nierembergia repens) (García y Santos et al. 2012), which affect sheep and, more rarely, cattle in Rio Grande do Sul state, Brazil. Enzootic calcinosis (EC) of unknown cause has been reported in Central Brazil, affecting sheep, goats, and cattle (Guedes et al. 2011).

Poisoning of sheep by $N$. rivularis in wetlands in the region of Batovi, Department of Tacuarembo, Uruguay has been reported since 1989 (Mederos et al. 1991), as well as near flooded areas in the Department of Rivera (García y Santos et al. 2012), on the islands of the Rincon del Bonete Lake (department of Durazno), and along the borders of the same lake in the department of Tacuarembo (Preliasco et al. 2014). The poisoning occurs between October (spring) and March (summer) with a mortality of 5-24\% (Table 1), affecting sheep of all ages, with the exception of suckling lambs (Mederos et al. 1991, García y Santos et al. 2012, Preliasco et al. 2014). Enzootic calcinosis was produced experimentally in sheep grazing for three months in a $625 \mathrm{~m}^{2}$ area of pasture infested by $N$. rivularis (García y Santos et al. 2012).

Cases of EC in sheep in Rio Grande do Sul state were initially described by Barros et al. (1970); later, poisoning was reproduced by the experimental administration of $N$. veitchii to rabbits (Riet-Correa et al. 1981) and sheep (RietCorrea et al. 1993). The disease has been described mainly in mountainous areas of the Planalto Medio and the south of Rio Grande do Sul state, Brazil (Riet-Correa et al. 1987, Barros et al. 1992,). In contrast, $N$. rivularis occurs mainly in low and humid areas in Uruguay (Fig.1) (García y Santos et al. 2012, Preliasco et al. 2014). Poisonings by $N$. veitchii and $N$. rivularis affect sheep of all ages from October to March, with the exception of suckling lambs. An increase in calcemia has been detected in October, reaching a peak in February, and decreasing from March (Riet-Correa et al. 1987). Despite the low lethality of EC caused by $N$. veitchii (1-25\%), the morbidity can be in the range of $1-80 \%$, which results in underestimated losses as most of the affected herd undergo weight loss that can be mistaken for malnutrition or parasitic infections (RietCorrea et al. 1987, Barros et al. 1992).

In Uruguay, an outbreak of poisoning by S. glaucophyllum, which contains glycosides derivates of $1,25(\mathrm{OH})_{2} \mathrm{D}_{3}$ (calcitriol), was reported in sheep near the streams of Solis Chico and Mosquito, department of Canelones, in which 15 ewes out of a flock of 100 sheep of different ages died (García y Santos et al. 2007). Poisoning by S. glaucophyllum has previously been described in cattle in the departments of Canelones, Colonia, Rocha (Riet-Correa et al. 1975) and Paysandú (Rivero et al. 1989). In Rocha, EC occurs between November and February in a wetland area of approximately 110,000 hectares, with morbidity ranging from $2-80 \%$ and averaging at $8-10 \%$ (RietCorrea et al. 1975). However, since 1975, most of the wetland areas have been dried for rice farming, which has decreased

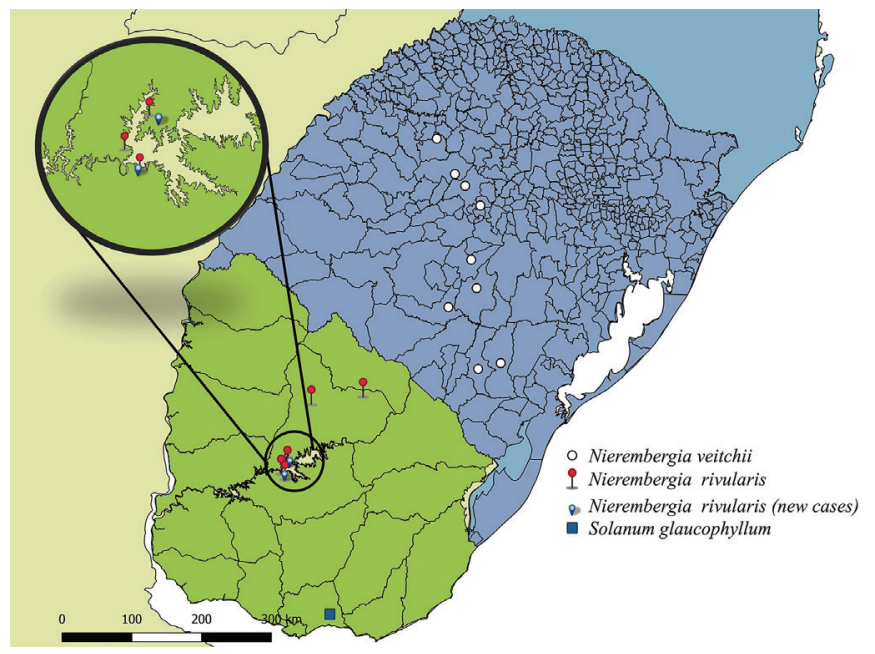

Fig.1. Location and geographic distribution of outbreaks of enzootic calcinosis in sheep poisoned by Nierembergia rivularis in Uruguay and Nierembergia veitchii in Rio Grande do Sul (RS), Brazil. The disease occurs mainly in humid areas in the departments of Tacuarembó, Rivera, and Durazno, Uruguay, and in high areas of the Planalto Medio/RS, Brazil. Inset of the borders of Rincon del Bonete lake, where the two outbreaks described in the present research and three others previously reported occurred.

Table 1: Outbreaks of enzootic calcinosis reported in sheep in Uruguay from 1989 to 2013

\begin{tabular}{|c|c|c|c|c|c|}
\hline \multirow{2}{*}{ Departments } & \multirow{2}{*}{ Period of outbreaks } & \multirow{2}{*}{ Plants } & \multicolumn{2}{|c|}{ Sheep } & \multirow{2}{*}{ References } \\
\hline & & & Total & Mortality (\%) & \\
\hline Tacuarembó & Out/1989 & Nierembergia rivularis & - & 6 & Mederos et al. 1991 \\
\hline Rivera & Dez/2005-Feb/2006 & N. rivularis & 200 & $6(12 / 200)$ & García y Santos et al. 2012 \\
\hline Tacuarembó & Oct/2012-Mar/2013 & N. rivularis & 199 & $5(10 / 199)$ & Preliasco et al. 2014 \\
\hline Tacuarembó & Oct/2012-Mar/2013 & N. rivularis & 400 & $12.5(50 / 400)$ & Preliasco et al. 2014 \\
\hline Durazno & Oct/2012-Mar/2013 & N. rivularis & 250 & $24(60 / 250)$ & Preliasco et al. 2014 \\
\hline Canelones & Aug-Dec/2006 & Solanum glaucophyllum & 100 & $15(15 / 100)$ & García y Santos et al. 2007 \\
\hline
\end{tabular}


the distribution and frequency of poisoning (Franklin RietCorrea, unpublished data).

Enzootic calcinosis is a chronic disease in sheep that is clinically characterized by anorexia, weight loss, stiff gait, and kyphosis with hypercalcemia and hyperphosphatemia (Barros et al. 1970, Riet-Correa et al. 1987). Exercise intolerance and sudden death caused by acute pulmonary edema are often observed during management practices (bathing, shearing, and dosing) of the flock (Mederos et al. 1991, Rissi et al. 2007, 2009, Preliasco et al. 2014). Soft tissue calcification, thyroid C cell hyperplasia, parathyroid chief cell atrophy, osteonecrosis, and osteopetrosis are the main changes observed in sheep poisoned by $N$. veitchii (Riet-Correa et al. 1987, 1993) and $N$. rivularis (García y Santos et al. 2012). N. veitchii has a toxic principle with a biological activity similar to $1,25(\mathrm{OH})_{2} \mathrm{D}_{3}$ (Riet-Correa et al. 1987).

This paper describes the epidemiological, clinical, and pathological findings of two outbreaks of EC in sheep associated with the spontaneous consumption of $N$. rivularis that occurred in Uruguay in the years 2016 and 2018.

\section{MATERIALS AND METHODS}

Epidemiological and clinical data were obtained from farmers and veterinarians in relation to two farms located in the departments of Durazno and Tacuarembó, Uruguay, in which EC outbreaks occurred. Clinical evaluation and blood sample collection for quantification of serum concentration of calcium and phosphorus were performed in one sheep from Outbreak A and 13 sheep from Outbreak B. One sheep from Outbreak A (Sheep A) that died spontaneously during herding and one from Outbreak B (Sheep B), which was euthanized, were autopsied. Organ samples including fragments of the femur cortex were collected, fixed in $10 \%$ buffered formalin ( $\mathrm{pH} 7.0$ ), processed routinely, cut at $4 \mu \mathrm{m}$, stained using the hematoxylin and eosin (HE) technique, and histologically evaluated. The samples of the femur were decalcified with 7\% nitric acid. Samples of Nierembergia sp. were collected and identified as Nierembergia rivularis Miers (syn. Nierembergia repens Ruiz \& Pav) (Cabrera 1979) and deposited under the number MVFA 34988 in the herbarium Ing. Agr. Bernardo Rosengurtt, at the Agronomy Faculty of the Republic University in Montevideo, Uruguay. A map showing the distribution and location of the cases of poisoning by Nierembergia spp. was constructed with Quantum Gis $2.14^{\circledR}$ software.

\section{RESULTS}

\section{Epidemiology and clinical signs}

Outbreak A was confirmed in February 2016 on a 50-hectare farm located on an island in the Rincon del Bonete lake, department of Durazno. In a flock of 110 sheep, 11 animals (10\%) exhibited clinical signs and eight (7.27\%) died. There were no cattle on the farm. Outbreak B was confirmed in January 2018 at a farm near the Rincon del Bonete lake, Cardozo region, Tacuarembó department. The disease occurred in a 90-hectare paddock on the border of the lake in which 220 sheep and 70 cattle were grazing. Twenty sheep (10\%) and four cows (2.8\%) had clinical signs. Sheep of different ages were affected, with the exception of suckling lambs. Seven sheep (3.1\%) died from December to February (summer) two to five months after the onset of the disease in spring. Laboratory data showed hyperphosphatemia $(8.5 \mathrm{mg} /$ $\mathrm{dL}$ - reference range: $5.0-7.3 \mathrm{mg} / \mathrm{dL}$ ) in the sheep that was necropsied. Normal calcium and phosphorus levels were observed in the other animals examined. The sample from Sheep A was not examined due to hemolysis.

The animals in both farms were raised in wetlands along the border of the Rincon del Bonete lake that was invaded by Nierembergia rivularis (Fig.2). The animals remained in this area all year round. The sheep exhibited clinical signs, such as progressive weight loss, retracted abdomen, kyphosis (Fig.3A), stiff gait, lameness, exercise intolerance, weakness, and recumbence. When managed, some sheep presented acute clinical manifestation with difficulty breathing, tachypnea, pulmonary edema, and recumbency that subsequently progressed to death. Annual outbreaks have been reported since 2012 on the farm located on the island and since 2011 on the farm located on the border of the lake.

\section{Gross and histological lesions}

The cadavers were emaciated and showed widespread soft tissue calcification. Muscular and elastic arteries were diffusely rigid, with marked loss of elasticity. The intimal surface was irregular with multiple white, prominent, and multifocal-to-coalescing intramural plaques (Fig.3B). The bicuspid and semilunar aortic valves exhibited similar plaques that were also identified in the tendinous and endocardial cords. The lungs did not collapse and showed multifocal calcification, mainly in the caudal lobe. The kidneys exhibited whitish, opaque, linear, and radially arranged striations in the cortical and medullary region (Fig.3C). Marked thickening of
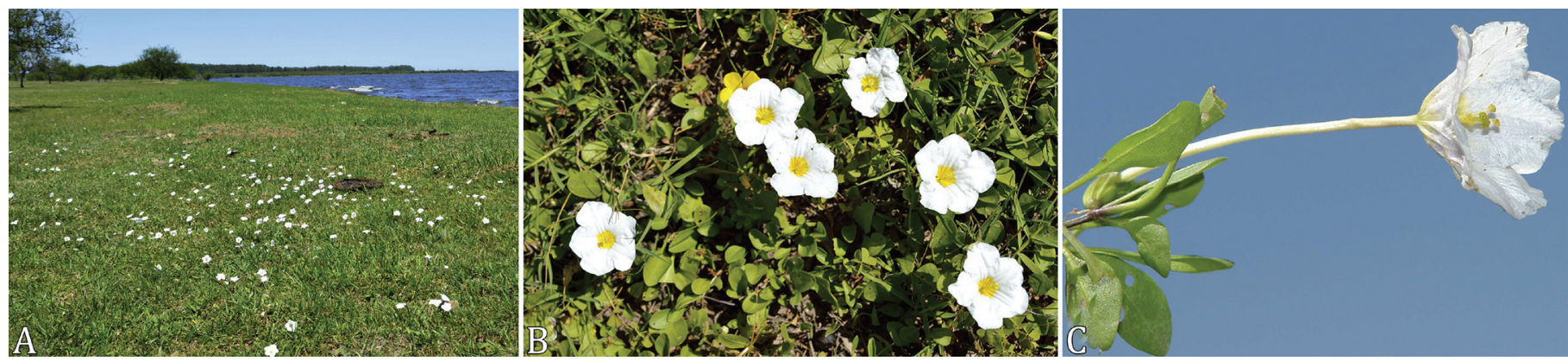

Fig.2. Location of outbreaks of enzootic calcinosis in sheep caused by Nierembergia rivularis in Uruguay. (A) Outbreak A. The border of the Rincon del Bonete lake is invaded by the plant. (B) Natural pasture invaded by Nierembergia rivularis. (C) Details of the flowering plant. 
cortical bone resulted in a reduction in the medullary space of the long bones.

Histologically, the intima of the carotid artery exhibited non-mineralized hyperplasia (Fig.3D) of variable intensity, with loss of undulation of the internal elastic lamina. Extensive areas of irregular deposition of basophilic material (calcification) expanded and disorganized the tunica media, sometimes with islands of bone and cartilaginous metaplasia, in addition to mild macrophage infiltrate. A thin layer of smooth muscle cells of the tunica media, adjacent to the adventitia, remained unchanged. Occasional calcification of the vasa vasorum wall was observed in the adventitia. The tunica media and intima of the aorta exhibited similar mineral deposits.

Mild to marked calcification of the alveolar septa occasionally replaced the lung parenchyma with dense areas of calcification with bone and chondroid metaplasia. Calcification was also verified on renal tissues, affecting the distal tubular lumen, arterioles, and interstitium. Thyroid C-cell hyperplasia and carcinoma were observed in Sheep A (Machado et al. 2020). Sheep B showed thyroid C-cell hyperplasia and parathyroid chief cell atrophy. The parathyroid was not examined in Sheep A. In Sheep B, the cortical bones were moderately thickened,
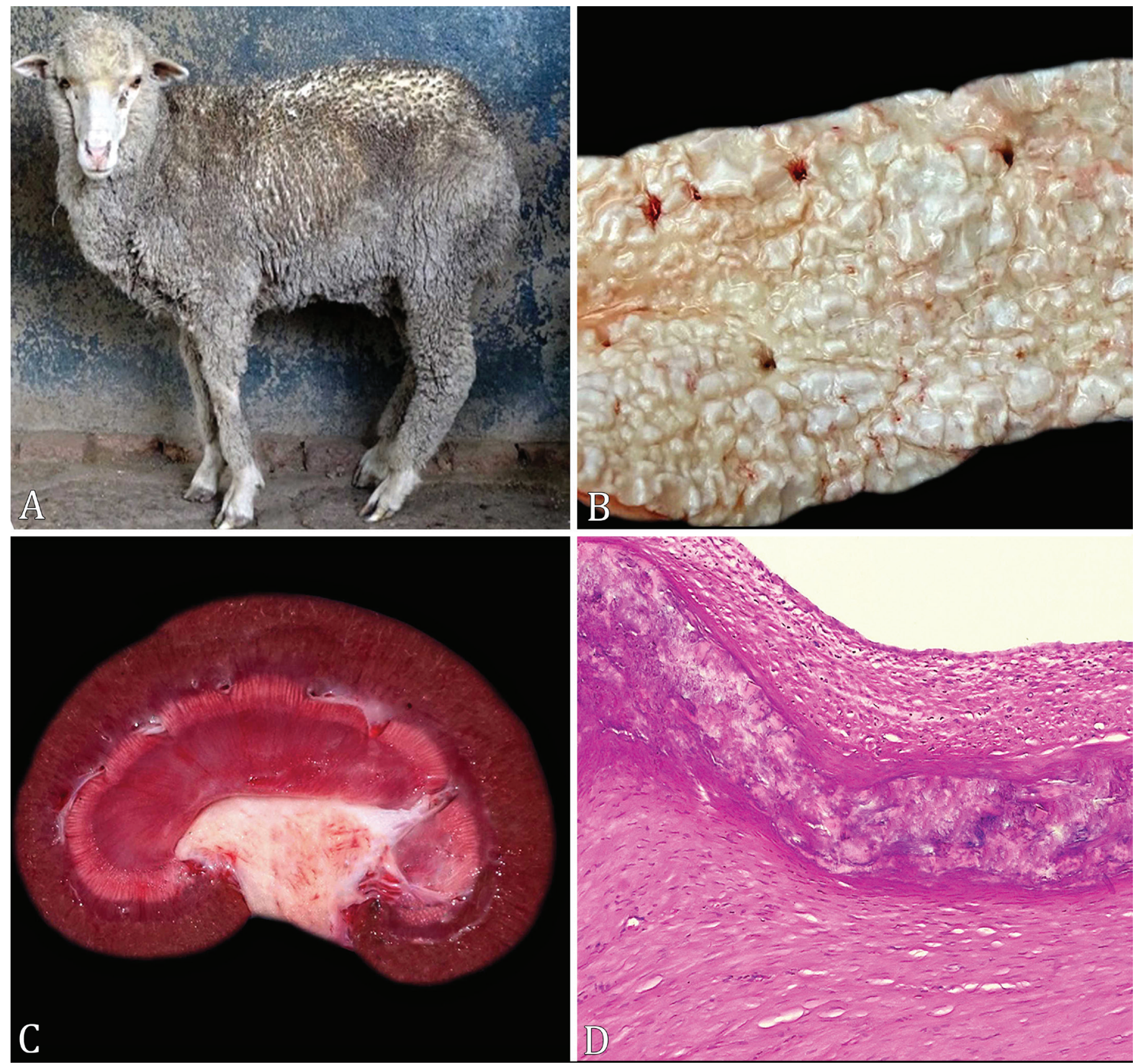

Fig.3. Enzootic calcinosis in sheep caused by Nierembergia rivularis in Uruguay. Outbreak B. (A) Sheep exhibiting kyphosis, retracted abdomen, poor body condition, and arched limbs. (B) Aorta. Diffusely irregular intimal surface with extensive calcified plates. (C) Kidney. Nephrocalcinosis characterized by white streaks radially arranged at the corticomedullary junction. (D) Carotid artery. Moderate intimal hyperplasia and tunica media calcification. HE, obj.10x. 
with increased osteoid and decreased Haversian channels. The trabecular bone of the epiphysis exhibited thickened trabeculae lined by sparse osteoclasts and osteoblasts. The proximal joint surface of the femoral head showed multifocal, disorganized, degenerated, and calcified chondrocytes.

\section{DISCUSSION}

The diagnosis of poisoning by Nierembergia rivularis in sheep in both outbreaks was made based on epidemiological, clinical, and pathological findings, in addition to the presence of the plant in the pastures. These findings were similar to those previously described in cases of EC (Barros et al. 1970, 1992, Riet-Correa et al. 1987, Mello 2003). Both farmers reported the sudden death of some sheep while being managed due to heart failure caused by severe calcification of heart valves and arteries, resulting in acute pulmonary edema and death (Barros et al. 1992, Rissi et al. 2007, 2009).

The mortality observed in both outbreaks $(3.1 \%$ and $7.1 \%)$, which was similar to previously reported rates (5-24\%) (Mederos et al. 1991, García y Santos et al. 2012, Preliasco et al. 2014), caused significant losses for the farmers. Economic losses must be considered in sheep that did not present with clinical signs (Riet-Correa et al. 1987). Therefore, poisoning by $N$. rivularis causes significant economic losses in some farms with paddocks located along the borders of the islands of the Rincon del Bonete lake, as well as wetlands near streams in the Tacuarembo and Rivera departments (Mederos et al. 1991, García y Santos et al. 2012, Preliasco et al. 2014).

Only one of the sheep examined showed hyperphosphatemia, and the serum concentrations of $\mathrm{Ca}$ were within normal concentrations in all sheep. Hypercalcemia and hyperphosphatemia were the results of remarkable changes in vitamin $\mathrm{D}$ poisoning (Mello 2003); these conditions have also been reported in cattle spontaneously poisoned by Trisetum flavescens (Köhler \& Libiseller 1970) and Cestrum diurnum (Durand et al. 1999), as well as in experimental poisoning by Solanum glaucophyllum in cattle (Döbereiner et al. 1971) and N. veitchii in sheep (Riet-Correa et al. 1993).

Hypercalcemia without hyperphosphatemia has been reported in horses (KrooK et al. 1975a) and cattle (Krook et al. $1975 b)$ poisoned by Cestrum diurnum and in sheep poisoned by $N$. veitchii (Riet-Correa et al. 1987). Hyperphosphatemia without hypercalcemia has been reported in cattle poisoned by Trisetum flavescens (Dirksen et al. 1970) and sheep poisoned by N. rivularis (Preliasco et al. 2014). In contrast, cattle naturally poisoned by $S$. glaucophyllum have been found to exhibit no changes (Döbereiner et al. 1971). Research by Döbereiner et al. (1971) suggested that animals with EC with normal Ca and $P$ serum levels had not consumed calcinogenic plants days before blood collection. Increased $\mathrm{Ca}$ and $\mathrm{P}$ concentrations are evident in animals soon after plant consumption and during experimental exposure (Döbereiner et al. 1971, Riet-Correa et al. 1993). The product of Ca x P values (>60) allows for a better evaluation of their metabolism (Gimeno 2001) and has been indicated for the diagnosis of subclinical cases of EC. Considered together, these reports demonstrate that an increase in $\mathrm{Ca}$ or $\mathrm{P}$ alone or an absence of changes in serum concentrations of these minerals does not exclude the diagnosis of EC.

To prevent and control poisoning, it should be noted that poisoning by $N$. rivularis and $N$. veitchii (Riet-Correa et al.
1987, Rissi et al. 2007, 2009) is seasonal and coincides with the vegetative growth of the plant, leading to the onset of clinical signs in the spring and higher mortality during the summer. There is no treatment for poisoning by calcinogenic plants, and the reversibility of the lesions is limited. When moved to pastures free of the plant, animals may exhibit slight recovery in weight gain, partially decreasing economic losses (Barros et al. 1992). Thus, it is recommended that immediately after the first signs or at the start of the spring, sheep should be moved to paddocks free from or with low amounts of $N$. rivularis. Disease seasonality and occurrence in low wetlands along borders of lakes and rivers allows for the use of rotative grazing, with a short-term stay on highly infested paddocks as a recommended measure of disease control.

As most of the $N$. rivularis plants on both farms were in areas surrounding water, the plants could be controlled using herbicides in restricted areas. Recently, various herbicides within the group of synthetic auxins and acetolactate synthase inhibitors were tested to control $N$. rivularis. In the short term the control of the aerial biomass was efficient (greater than 95\%) with mixtures of the 2,4-D + Metsulfuron; 2,4-D + Starane; or 2,4-D + Lexus. However, in the following growing season, although to a lesser degree, the infestation by this species continued. Control in the medium and long term was much better when, in addition to the application of herbicides, continuous overgrazing of the treated area was avoided, in order to favor the competition of the forage species of interest. The chemical recommendation consists of the application of 2 liters of 2,4-D plus 200 cc of Tordon plus 10g Metsulfuron per hectare with the aim of achieving good control in the short term and maintaining a residual control in the medium term. However, to avoid the annual reapplication of herbicides, it is necessary to adjust grazing management (Alejandro Garcia, Instituto Nacional de Investigación Agropecuaria, INIA, Uruguay, unpublished data).

Cattle are less affected by $N$. veitchii poisoning than sheep due to the different feeding habits of both species and the morphological characteristics of the plant (Riet-Correa et al. 1987). In the present study, in Outbreak B, cattle grazing in the same paddock as sheep developed clinical signs that were suggestive of EC. Further studies in areas of cattle breeding invaded by $N$. rivularis are necessary to confirm the occurrence and importance of EC in this species.

The differential diagnosis of EC in sheep includes paratuberculosis (Johne's disease), which is a chronic debilitating disease affecting sheep that is characterized by progressive weight loss, exercise intolerance, and, occasionally, diarrhea (Giannitti et al. 2018). However, granulomatous enteritis observed histologically and the occurrence of diarrhea in some cases of paratuberculosis assist in the differentiation of the diseases. Gastrointestinal parasitosis, mainly haemonchosis, which occurs frequently in the spring and summer, should also be considered in the differential diagnosis.

\section{CONCLUSIONS}

Poisoning by Nierembergia rivularis in Uruguay is a chronic disease in sheep, sometimes causing sudden death due to acute pulmonary edema induced by heart failure. It causes losses in sheep farming in wetlands near rivers or streams in the departments of Tacuarembó and Rivera and in the islands in the Rincon del Bonete lake. 
Like other calcinogenic plants, $N$. rivularis causes soft tissue calcification (enzootic calcinosis).

The only preventive measure is to avoid grazing sheep for long periods from October to February in paddocks invaded by the plant.

Acknowledgements.- Special thanks to Anderson Saravia ("Instituto Nacional de Investigación Agropecuaria" - INIA, La Estanzuela) for the aid in the making of the map. A postgraduate scholarship was provided by INIA, Uruguay.

Conflict of interest statement.- The authors declare that there are no conflicts of interest.

\section{REFERENCES}

Barros S.S., Driemeier D., Santos M.N. \& Guerrero J.A.M. 1992. Evolução clínica e reversibilidade das lesões da calcinose enzoótica dos ovinos induzida por Nierembergia veitchii. Pesq. Vet. Bras. 12(1/2):5-10.

Barros S.S., Pohlenz J. \& Santiago C. 1970. Zur Kalzinose beim Schaf. Dtsch. Tierärztl. Wochenschr. 77:346-349.

Cabrera A.L. 1979. Solanaceae, p.346-452. In: Burkart A. (Ed.), Flora Ilustrada de Entre Ríos. INTA, Buenos Aires.

Dirksen G., Plank P., Spiess A., Hänichen T. \& Dämmrich K. 1970. Über eine enzootische "Kalzinose" beim Rind. 1. Klinische Beobachtungen und Untersuchungen. Dtsch. Tierärztl. Wschr. 77:321-338

Döbereiner J., Tokarnia C.H., Costa J.B.D., Campos J.L.E. \& Dayrell M.S. 1971. "Espichamento", intoxicação de bovinos por Solanum malacoxylon, no Pantanal de Mato Grosso. Pesq. Agropec. Bras. 6:91-117.

Durand R., Figueredo J.M. \& Mendoza E. 1999. Intoxication in cattle from Cestrum diurnum. Vet. Hum. Toxicol. 41(1):26-27. <PMid:9949481>

García y Santos C., Pereira R., Capelli A., Domingez R., Bonino F., Goyen J.M. \& Arago S. 2007. Intoxicación espontánea em ovinos por ingestión de Solanum glucophyllum (malacoxylon) en Uruguay. XXXV Jornadas Uruguayas de Buiatría, Paysandú, p.274-275. (Resumo)

García y Santos C., Pereira R., Etcheberry G., Goyen J. M., Pérez W., Capelli A. \& Riet-Correa F. 2012. Enzootic calcinosis caused by Nierembergia rivularis in sheep. J. Vet. Diagn. Invest. 24(2):423-426. <https://dx.doi. org/10.1177/1040638711435143><PMid:22379059>

Giannitti F., Fraga M., Caffarena R.D., Schild C.O., Banchero G., Armién A.G., Travería G., Marthaler D., Wells S.J. \& Riet-Correa F. 2018. Mycobacterium paratuberculosis sheep type strain in Uruguay: Evidence for a wider geographic distribution in South America. J. Infect. Dev. Ctries 12(3):190195. <http://dx.doi.org/10.3855/jidc.9751><PMid:31829995>

Gimeno E.J. 2001. Calcinosis enzoótica em rumiantes: Un problema vigente de la ganadería nacional. Anales Acad. Nac. Agron. Vet. 207-232.

Guedes K.M.R., Colodel E.M., Castro M.B., Souza M.A., Arruda L.P., Dianezi D.M., Borges J.R.J. \& Riet-Correa F. 2011. Calcinose enzoótica em ruminantes no Brasil Central. Pesq.Vet. Bras. 31(8):643-648. <https://dx.doi.org/10.1590/ S0100-736X2011000800002>

Iglesias V.J., Costa E.F. \& Gimeno, E.J. 2008. Calcinosis enzoótica en caprinos en la provincia de San Luis (XXXI Congreso Argentino de Producción Animal, Potrero de los Funes, San Luis). Revta Arg. Prod. Anim. 28(Supl.1):333334. (Resumo)

Köhler H. \& Libiseller R. 1970. Über das Aufreten der sogenannten "Weidekrankheit" bei Kühen in Österreich in Zusammenhang mit Düngung und Fütterung. Zbl. VetMed. 17(4):289-337. <https://dx.doi. org/10.1111/j.1439-0442.1970.tb00787.x>

Krook L., Wasserman R.H., McEntee K., Brokken T.D. \& Teigland M.B. 1975a. Cestrum diurnum poisoning in Florida cattle. Cornell Vet. 65(4):557-575. <PMid:1192749>
Krook L., Wasserman R.H., Shiverly J.N., Tashjian A.H., Brokken T.D., Morton J.F., 1975b. Hypercalcemia and calcinosis in Florida horses: implication of the shrub, Cestrum diurnum, as the causative agent. Cornell Vet. 65(1):2656. <PMid:1112096>

Machado M., Preliasco M., Schild C.O., Costa R.A., Balserini A., Giannitti F. \& Riet-Correa F. 2020. Thyroid parafollicular cell hyperplasia and carcinoma in a sheep with enzootic calcinosis due to Nierembergia rivularis poisoning. Arq. Bras. Med. Vet. Zootec. 72(4):1561-1565. <https://dx.doi. org/10.1590/1678-4162-11795>

Mederos A., Easton C., Paullier C., Gago M., Franchi M. \& Bove R. 1991. Comprobación de intoxicación por Nierembergia repens en ovinos del Uruguay. Anales X Jornadas veterinarias de ovinos, Tacuarembó, Uruguay. 4p. (Resumo)

Mello J.R.B. 2003. Calcinosis: Calcinogenic plants. Toxicon 41(1):1-12. <https://dx.doi.org/10.1016/s0041-0101(02)00241-6><PMid:12467655>

Odriozola E.O., Rodríguez A.M., Micheloud J.F., Cantón G.F., Caffarena R.D., Gimeno E.J., Bodega J.J., Gardey P., Iseas F.B. \& Giannitti F. 2017. Enzootic calcinosis in horses grazing Solanum glaucophyllum. J. Vet. Diagn. Invest. 30(2):286-289. <https://dx.doi.org/10.1177/1040638717746447> $<$ PMid:29202673>

Preliasco M., López F., Balserini A., Freire I., Collazo S., Uriarte G., Bove R. \& González A.C. 2014. Descripción de tres focos de calcinosis enzoótica en ovinos (Intoxicación por Nierembergia repens Ruiz \& Pav.) diagnosticados en Uruguay. XLII Jornadas Uruguayas de Buiatria, Paysandú, p.257-259. (Resumo)

Riet-Correa F., Méndez M.C., Schild A.L. \& Petiz C.A. 1993. Enzootic calcinosis in sheep: experimental reproduction with Nierembergia veitchii (Solanaceae). Pesq. Vet. Bras. 13(1/2):21-24

Riet-Correa F., Méndez M.C., Schild A.L., Santos E.C. \& Scarsi R. 1981. Experimentos em coelhos sugerem Nieremhergia veitchii como causa de calcinose enzoótica em ovinos do Rio Grande do Sul. Pesq. Agropec. Bras. 16(5):727-732.

Riet-Correa F., Riet Correa I. \& Bellagamba C. 1975. Calcificación metastásica enzoótica (enteque seco) en bovinos del Uruguay. Veterinaria, Uruguay, 12(60):15-23.

Riet-Correa F., Schild A.L., Mendez M.C, Wasserman R. \& Krook L. 1987. Enzootic calcinosis in sheep caused by the ingestion of Nierembergia veitchii (Solanaceae). Pesq. Vet. Bras. 7(3):85-95.

Rissi D.R., Brown C.C. \& Barros C.S.L. 2009. Chronic and acute clinical manifestations associated with systemic mineralization caused by ingestion of Nierembergia veitchii in sheep in southern Brazil. Small Rumin. Res. 87(1/3):102-104.<https://dx.doi.org/10.1016/j.smallrumres.2009.09.035>

Rissi D.R., Rech R.R., Pierezan F., Kommers G.D. \& Barros C.S.L. 2007. Poisoning in sheep by Nierembergia veitchii: observations in four outbreaks. Ciência Rural 37(5):1393-1398. <https://dx.doi.org/10.1590/S010384782007000500027>

Rivero R., Quintana S., Féola R. \& Haedo F. 1989. Principales enfermedades diagnosticadas en el área de influencia del laboratorio de diagnóstico regional noroeste del C. I. Vet. "Miguel Rubino". XVII Jornadas Uruguayas de Buiatria, Paysandú, Uruguay, p.1-73.

Rossanigo C.E., Pablo R.J., Walter P., Manuel C.P.J., Giselle R.C. \& Carmen L.E. 2017. Enzootic calcinosis in argentine goats due to presumptive intoxication with Solanum stuckertii Bitter. International Symposium of the World Association of Veterinary Laboratory Diagnosticians, Sorrento, Italy, p.227. (Resumo)

Santos C.E.O., Pescador C.A., Ubiali D.G., Colodel E.M., Souza M.A., Silva J.A., Canola J.C. \& Marques L.C. 2011. Intoxicação natural por Solanum glucophyllum (Solanaceae) em búfalos no Pantanal Matogrossense. Pesq. Vet. Bras. 31(12):1053-1058. <https://dx.doi.org/10.1590/S0100736X2011001200003> 